\title{
Protective Role of Complement C5a in an Experimental Model of Staphylococcus aureus Bacteremia
}

\author{
Maren von Köckritz-Blickwede ${ }^{a}$ Stephanie Konrad ${ }^{b}$ Simon Foster $^{c}$ \\ J. Engelbert Gessner ${ }^{\mathrm{b}} \quad$ Eva Medina ${ }^{\mathrm{a}}$ \\ a Infection Immunology Research Group, Helmholtz Center for Infection Research, Braunschweig, \\ ${ }^{b}$ Clinic for Immunology and Rheumatology, Hanover Medical School, Hanover, Germany; \\ 'Department of Molecular Biology and Biotechnology, University of Sheffield, Western Bank, Sheffield, UK
}

\section{Key Words \\ Bacteremia $\cdot$ Complement C5a • Infection, susceptibility • \\ Staphylococcus aureus}

\begin{abstract}
The complement system is a key component of the innate immune response. Here, we have examined the role of complement anaphylatoxin $\mathrm{C} 5 \mathrm{a}$ in an experimental model of Staphylococcus aureus bacteremia. Our data provide compelling evidence for a protective role of $\mathrm{C} 5 \mathrm{a}$ during staphylococcal bloodstream infection.
\end{abstract}

Copyright $\odot 2009$ S. Karger AG, Basel

\section{Introduction}

Staphylococcus aureus is an important human pathogen that causes a wide spectrum of clinical manifestations, ranging from superficial cutaneous infections to life-threatening systemic diseases. The impact of $S$. aureus infection on human health has dramatically increased as a result of its remarkable ability to become resistant to antibiotics [1]. Given the increasing number and severity of $S$. aureus infections worldwide [2], it is important to understand the pathophysiology of these infections.
The complement system is a fundamental component of the immune response to infection with many pathogens [3]. Activation of complement by microbes proceeds through a sequence of proteolytic activation events, that results in the formation of bacterium-bound opsonins and the anaphylatoxins C3a, C4a and C5a [3, 4]. C5a is regarded as the most potent chemoattractant for neutrophils and monocytes, contributing to a rapid mobilization of phagocytic cells to the site of infection to promote pathogen clearance [5]. In addition, C5a stimulates oxidative metabolism, enhances expression of adhesion molecules in neutrophils, and activates the coagulation pathway [4].

In the context of $S$. aureus infections, mice deficient in the production of complement $\mathrm{C} 5$ have been reported to have decreased pulmonary clearance of $S$. aureus after aerosol infection [6]. In addition, it has been shown that deletion of $\mathrm{C} 5 \mathrm{aR}$, a receptor for $\mathrm{C} 5 \mathrm{a}$, predisposed mice to colonization with staphylococci in the lungs [7]. However, little is known about the role of C5 during bloodstream infections, one of the most life-threatening diseases caused by $S$. aureus [8]. The present study was designed to evaluate the role of complement factor $\mathrm{C} 5$ and its cleavage product $\mathrm{C} 5 \mathrm{a}$ for host defense during staphylococcal bacteremia using an experimental murine model of infection.

\section{KARGER}

Fax +4161306 1234

E-Mail karger@karger.ch

www.karger.com
(C) 2009 S. Karger AG, Basel

1662-811X/10/0021-0087\$26.00/0

Accessible online at:

www.karger.com/jin
PD Dr. Eva Medina

Infection Immunology Research Group

Helmholtz Center for Infection Research

Inhoffenstrasse 7, DE-38124 Braunschweig (Germany)

Tel. +49 5316181 4500, Fax +495316181 4499, E-Mail eva.medina@helmholtz-hzi.de 


\section{Methods}

\section{Mice}

Inbred, pathogen-free, 8- to 12 -week-old C57BL/6 JOlaHsd, DBA/2 OlaHsd, and B6D2F1/OlaHsd-F1-hybrids (generated after crossing female C57BL/6 with male DBA/2 mice) were purchased from Harlan Winkelmann (Borchen, Germany). Congenic C5-deficient B10.D2-Hc0 H2d/SnJ and the corresponding C5sufficient B10.D2-Hc1 H2d/SnJ mice were purchased from Jackson Laboratory (Bar Harbor, Maine, USA). All experiments were approved by the appropriate national ethical board (Niedersächsisches Landesamt für Verbraucherschutz und Lebensmittelsicherheit, Oldenburg, Germany).

\section{Infection Model}

Mice were inoculated intravenously with $4 \times 10^{7} \mathrm{CFU}$ of $S$. aureus SH1000 in $0.2 \mathrm{ml}$ PBS, as described previously [9]. For determination of bacterial loads, infected mice were sacrificed by $\mathrm{CO}_{2}$ asphyxiation, their kidneys removed, homogenized in PBS and bacterial colonies were enumerated after plating serial dilutions onto blood agar.

\section{Serum Adoptive Transfer}

DBA/2 mice were intravenously injected (200 $\mu \mathrm{l} /$ mouse) 30 min prior to infection with serum from C $57 \mathrm{BL} / 6$ mice that was either left untreated (complement-sufficient serum) or heat-inactivated at $60^{\circ} \mathrm{C}$ for $30 \mathrm{~min}$ (complement-deficient serum).

\section{Treatment with Recombinant C5a ( $\mathrm{CC} 5 \mathrm{a}$ )}

DBA/2 mice were injected intravenously with 1 dose $(2 \mu \mathrm{g})$ of murine rC5a (R\&D Systems, Wiesbaden, Germany; diluted in 200 $\mu \mathrm{l}$ PBS $+0.1 \%$ BSA) 30 min prior to infection. Control mice were injected intravenously with $200 \mu \mathrm{l}$ of PBS $+0.1 \%$ BSA. In some experiments, DBA/2 mice received 2 additional doses of $2 \mu \mathrm{g}$ rC5a given intraperitoneally at 6 and $12 \mathrm{~h}$ following bacterial inoculation.

\section{Determination of C5a Serum Concentration}

Serum C5a levels were determined by ELISA. Immuno-MaxiSorb 96-well microtiter plates (Nunc, Wiesbaden, Germany) were coated overnight at $4^{\circ} \mathrm{C}$ with $50 \mu \mathrm{l}$ of $4 \mu \mathrm{g} / \mathrm{ml}$ purified rat antimouse C5a IgG (BD Pharmingen, San Diego, Calif., USA). Wells were blocked with $1 \%$ skim milk in PBS containing $0.05 \%$ Tween20 (Merck, Darmstadt, Germany) and incubated for $2 \mathrm{~h}$ at room temperature. After 3 washes with PBS, serum samples or recombinant mouse C5a (R\&D Systems, Minneapolis, Minn., USA) at concentrations of $400 \mathrm{ng} / \mathrm{ml}$ to $12.5 \mathrm{ng} / \mathrm{ml}(50 \mu \mathrm{l} /$ well diluted in PBS containing $0.1 \%$ skim milk and $0.05 \%$ TWEEN-20) were added and incubated at $37^{\circ} \mathrm{C}$ for $2 \mathrm{~h}$. After 3 washes, $50 \mu \mathrm{l}$ biotinylated rat anti-mouse C5a antibody (BD Pharmingen, San Diego, Calif., USA) was added at $2 \mu \mathrm{g} / \mathrm{ml}$ for $2 \mathrm{~h}$ at $37^{\circ} \mathrm{C}$, followed by 3 washing steps and $1 \mathrm{~h}$ incubation with 1:5,000 diluted streptavidin-peroxidase (Acris, Hiddenhausen, Germany). After 3 final washes, plates were colorimetrically developed with $o$-phenylenediamine dihydrochloride (Sigma-Aldrich, Taufkirchen, Germany) as described in the manufacturer's instructions, and reaction stopped with $0.5 \mathrm{M}$ sulfuric acid, prior to measuring the absorbance at $490 \mathrm{~nm}$. All samples were analyzed in duplicate and results calculated from the means of duplicate sample analysis.
Histopathological Examination

Kidneys of mice were fixed in $10 \%$ buffered neutral formalin solution, embedded in paraffin, and then cut into 3 - $\mu \mathrm{m}$-thick sections. Sections were stained with hematoxylin and eosin and analyzed using an Olympus Bx51 microscope.

\section{Statistics}

Statistical analysis was performed using GraphPad Prism 4.0. All data are presented as mean \pm SD. Comparison between 2 groups was made by unpaired t test. Comparison of survival curves was performed by use of Log-rank (Mantel Cox) test (minimum $n=9$ mice). $\mathrm{p}$ values of $\leq 0.05$ were considered significant.

\section{Results and Discussion}

We have recently shown that different mouse strains vary in their degree of susceptibility to intravenously inoculated S. aureus [9]. Susceptible mice develop severe infection associated with high bacterial loads in kidneys and $100 \%$ mortality within 1-3 days after intravenous inoculation with $4 \times 10^{7} \mathrm{CFU}$ of $S$. aureus strain SH1000. Interestingly, the most susceptible strains (A/J and $\mathrm{DBA} / 2$ ) have a genetic deficiency that results in the impaired production of complement C5 [10]. This is of particular interest, since human individuals deficient in complement C5 have been shown to be strongly predisposed to recurrent infections caused by $S$. aureus [11]. It has also been reported that individuals heterozygous for C5 deficiency exhibit half-normal levels of C5a, but are nevertheless healthy individuals with no notable infectious episodes [12]. To determine whether this was also the case in the murine system, we compared the serum levels of the complement $\mathrm{C} 5$ degradation product, $\mathrm{C} 5 \mathrm{a}$, in $\mathrm{F} 1\left(\mathrm{C}^{+/-}\right)$progeny resulting from crossing $\mathrm{C} 57 \mathrm{BL} / 6$ $\left(\mathrm{C}^{+/+}\right)$with $\mathrm{C} 5$-deficient $\mathrm{DBA} / 2\left(\mathrm{C}^{-/-}\right)$mice at $24 \mathrm{~h}$ after bacterial inoculation. Similar to humans, the levels of $\mathrm{C} 5 \mathrm{a}$ in infected $\mathrm{F} 1\left(\mathrm{C}^{+/-}\right)$mice were significantly lower than those measured in $\mathrm{C} 57 \mathrm{BL} / 6\left(\mathrm{C}^{+/+}\right)$animals (fig. 1a). $\mathrm{C} 5 \mathrm{a}$ in serum of infected DBA/2 $\left(\mathrm{C}^{-/-}\right)$mice were below detection levels (fig. 1a). Furthermore, F1 $\left(\mathrm{C}^{+/-}\right)$mice were significantly more resistant to $S$. aureus infection than DBA/2 $\left(\mathrm{C}^{-/-}\right)$mice, as shown by a better capacity to control bacterial growth in the kidneys (fig. 1b) and improved survival (fig. 1c). These results indicate that the generation of $\mathrm{C} 5$, at least to half-normal levels, may have an impact on the resistance of mice to staphylococcal bloodstream infection.

To confirm this assumption, we determined whether treatment of DBA/2 $\left(\mathrm{C} 5^{-l-}\right)$ mice with serum from a C5sufficient strain $(\mathrm{C} 57 \mathrm{BL} / 6)$ could enhance their resis- 

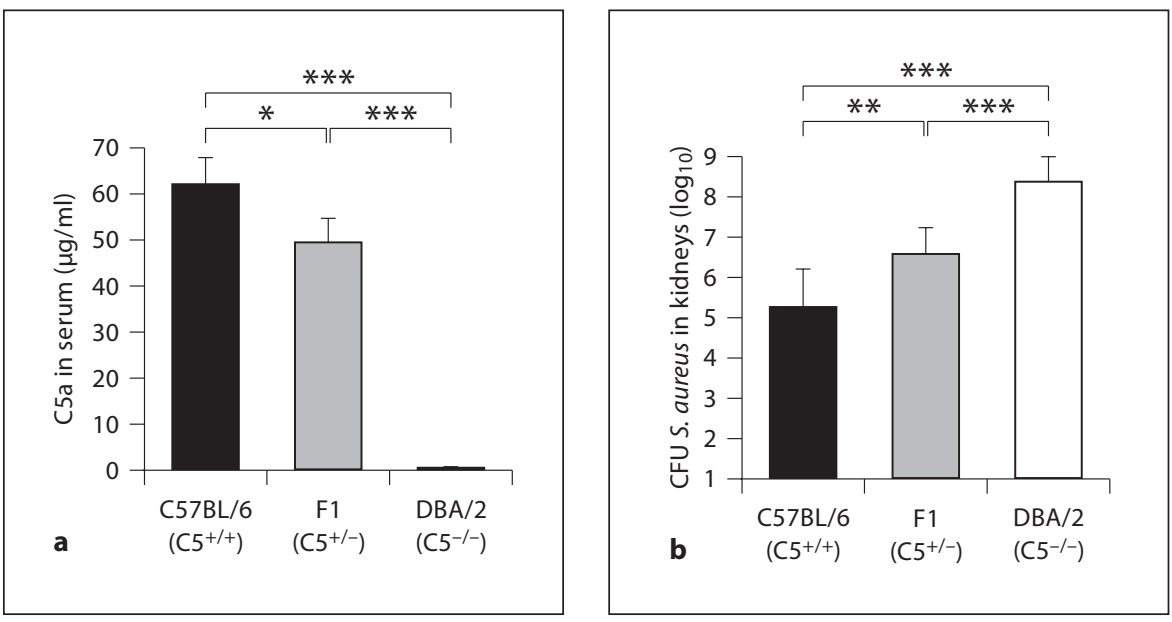

Fig. 1. Differential susceptibility of C57BL/6 $\left(\mathrm{C5}^{+/+}\right)$mice, DBA/2 $\left(\mathrm{C} 5^{-/-}\right)$mice and their $\mathrm{F} 1\left(\mathrm{C}^{+/-}\right)$progeny to $S$. aureus bloodstream infection. Levels of C5a in serum (a) and bacterial loads in kidneys (b) of C57BL/6 $\left(\mathrm{C}^{+/+}\right)$(black bar), DBA/2 $\left(\mathrm{C}^{-/-}\right)$(white bar), and F1 (grey bar) mice at $24 \mathrm{~h}$ after intravenous inoculation with $S$. aureus. Each bar represents the mean \pm SD of determination of a minimum of 3 (a) or 5 (b) mice/group. c Survival curves of $\mathrm{C} 57 \mathrm{BL} / 6\left(\mathrm{C}^{+/+}\right), \mathrm{DBA} / 2\left(\mathrm{C}^{-/-}\right)$, and F1 $\left(\mathrm{C}^{+/-}\right)$mice after intravenous inoculation with $4 \times 10^{7} \mathrm{CFU}$ of $S$. aureus. ${ }^{*} \mathrm{p}<0.05$; ${ }^{* *} \mathrm{p}<0.01{ }^{* * *} \mathrm{p}<0.001$.

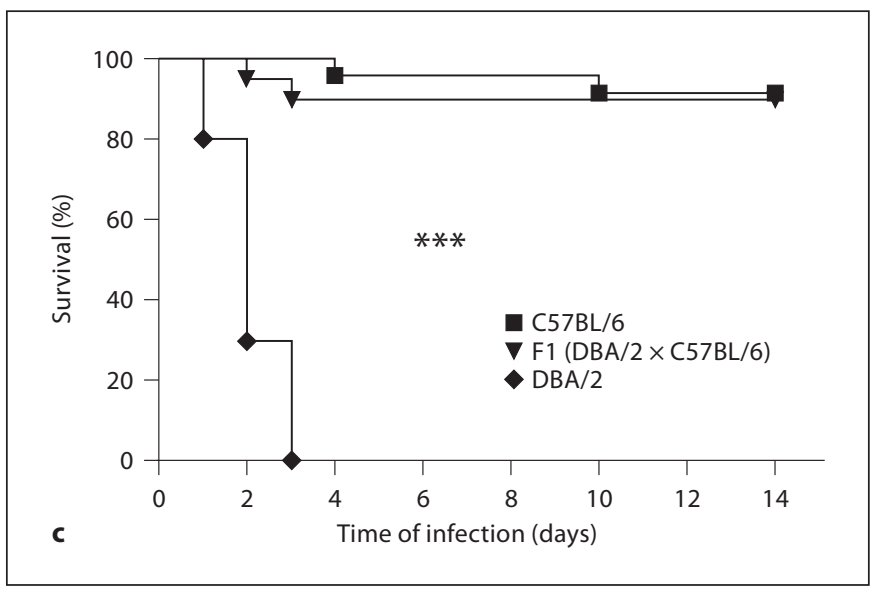

tance to $S$. aureus infection. For this purpose, DBA/2 $\left(\mathrm{C}^{-/-}\right)$mice were adoptive transferred with complementsufficient (normal serum obtained from C57BL/6 mice) or complement-deficient (heat-inactivated serum obtained from C57BL/6 mice) serum prior to infection with S. aureus. Our results show that DBA/2 mice receiving complement-sufficient serum survived significantly longer (fig. 2a) and exhibited significant lower bacterial loads in the kidneys at $24 \mathrm{~h}$ of infection (fig. $2 \mathrm{~b}$ ) than DBA/2 mice either untreated of treated with complement-deficient serum. In good correlation to these data, examination of kidney tissue sections obtained from $S$. aureus-infected mice at $24 \mathrm{~h}$ after bacteria inoculation revealed a diffuse and confluent inflammation with extensive areas of tissue destruction containing abundant bacteria in the kidneys of infected DBA/2 mice receiving complement-deficient serum (fig. 2c, arrow on panel ii). In contrast, no signs of histological tissue damage were detected in the kidney sections of mice receiving comple- ment-sufficient serum (fig. 2c, panel iii). Therefore, adoptive transfer of complement C5 from C57BL/6 serum resulted in delayed development of pathology and enhanced the resistance of DBA/2 $\left(\mathrm{C}^{-/-}\right)$mice to $S$. aureus infection.

The activation of $\mathrm{C} 5$ during infection results in the generation of the degradation products $\mathrm{C} 5 \mathrm{a}$ and $\mathrm{C} 5 \mathrm{~b}$ [35]. The anaphylatoxin $\mathrm{C} 5 \mathrm{a}$ is a potent chemoattractant for phagocytic cells and exerts an immunoregulatory role during inflammation [3-5], while C5b is involved in the formation of the membrane attack complex (MAC) consisting of C5b, C6, C7, C8 and C9. As the activity of MAC is largely limited to Gram-negative bacteria [3], we hypothesized that the protective role of C5 during S. aureus bacteremia is entirely mediated by $\mathrm{C} 5 \mathrm{a}$. Indeed, complement $\mathrm{C} 6$-deficient $\left(\mathrm{C6}^{-/-}\right) \mathrm{C} 57 \mathrm{BL} / 6$ mice, which are incapable of forming MAC, were as resistant to $S$. aureus as wild type mice (online suppl. fig. S1, available at www. karger.com/doi/10.1159/000247157). 

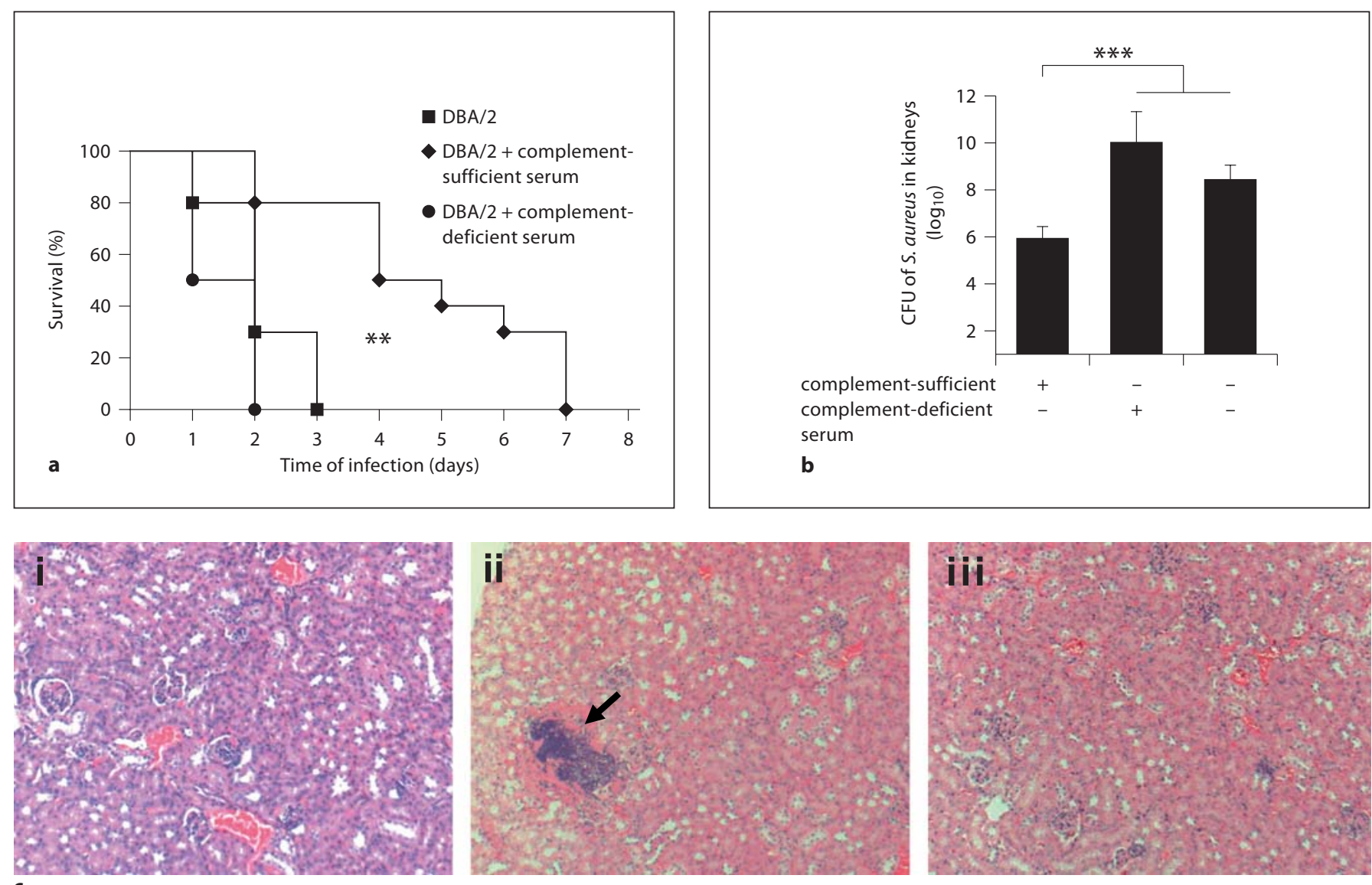

Fig. 2. Effect of treatment with complement-sufficient serum, complement-deficient serum or $\mathrm{rC} 5 \mathrm{a}$ in the response of $\mathrm{DBA} / 5$ $\left(\mathrm{C}^{-l-}\right)$ mice to intravenous $S$. aureus infection. a Survival of either untreated DBA/2 $\left(\mathrm{C}^{-/-}\right)$or DBA/2 $\left(\mathrm{C}^{-/-}\right)$mice after passive transfer with $200 \mu \mathrm{l}$ of either complement-sufficient or complement-deficient serum after intravenous infection with $S$. aureus. b Bacterial loads in kidneys of the above-mentioned mice at $24 \mathrm{~h}$ of infection (minimum $\mathrm{n}=6$ mice). $\mathrm{c}$ Histological examination of kidney tissue obtained from either uninfected DBA/2 $\left(\mathrm{C}^{-/-}\right)$ mice (panel i) or S. aureus-infected DBA/2 $\left(\mathrm{C} 5^{-/}\right)$animals treated with either complement-deficient (panel ii) or complement-sufficient (panel iii) serum. The black arrow indicates abscess formation containing abundant bacteria. $\mathbf{d}$ Bacterial loads in kidneys of DBA/2 $\left(\mathrm{C}^{-/-}\right)$mice treated with either 1 dose of rC5a $30 \mathrm{~min}$ prior to bacterial inoculation $(n=14)$, or 3 consecutives doses of rC5a (30 min prior to and 6 and $12 \mathrm{~h}$ after bacterial inoculation; $\mathrm{n}=4$ ) at $24 \mathrm{~h}$ after intravenous infection with $S$. aureus. Each bar represents the mean \pm SD. ${ }^{* *} \mathrm{p}<0.01 ;{ }^{* * *} \mathrm{p}<0.001$.

To provide direct evidence for a protective role of $\mathrm{C} 5 \mathrm{a}$ during S. aureus bacteremia, DBA/2 $\left(\mathrm{C}^{-/-}\right)$mice were therapeutically treated with 1 or 3 doses of $\mathrm{rC} 5 \mathrm{a}$, and the bacterial loads in kidneys were determined $24 \mathrm{~h}$ after intravenous bacterial inoculation. As shown in figure 2d,

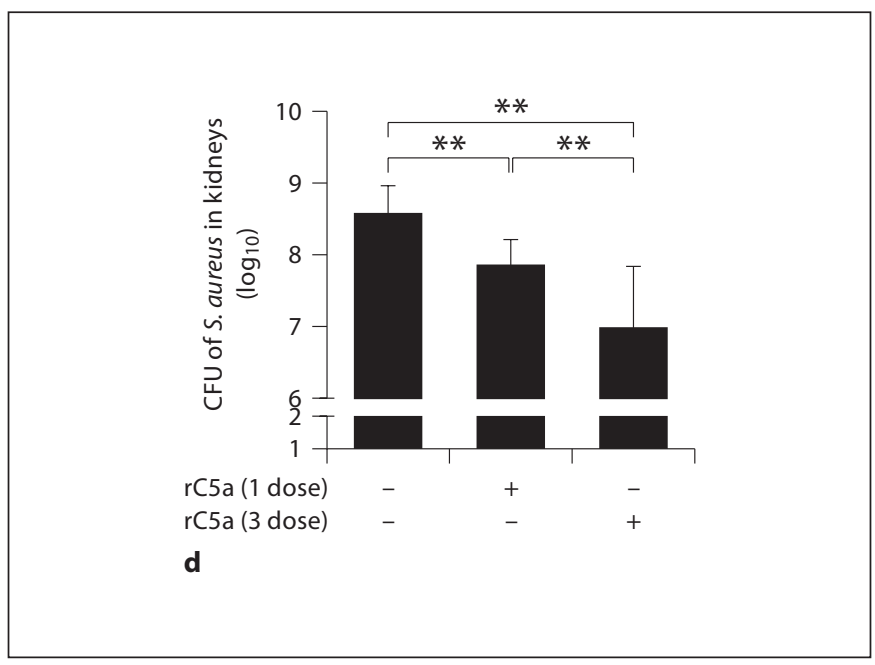

treatment with rC5a significantly improved control of bacterial growth in a dose-dependent manner.

Finally, as C56BL/6 and DBA/2 mice are genetically very heterogeneous, we used congenic B10.D2-Hc0 $\left(\mathrm{C}^{-/-}\right)$mice, which differ from B10.D2-Hc1 $\left(\mathrm{C}^{+/+}\right)$con- 

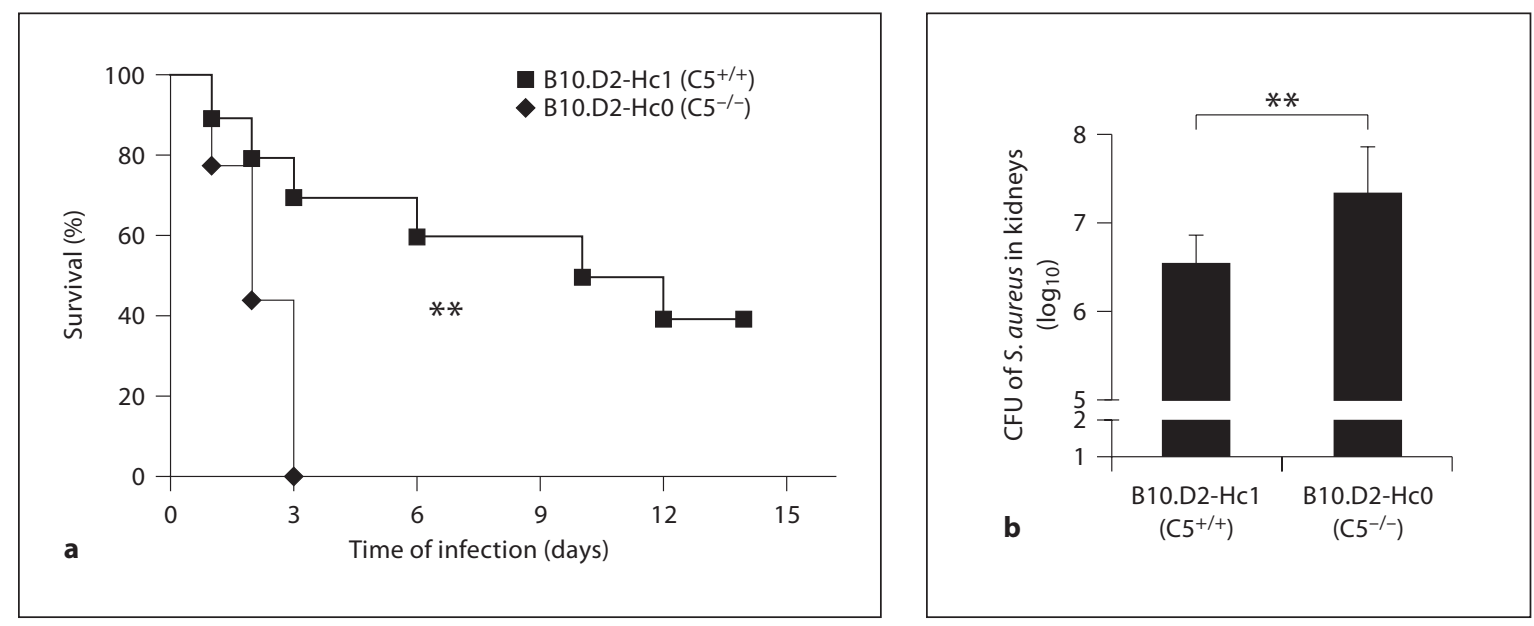

Fig. 3. Response of congenic B10.D2-Hc0 $\left(\mathrm{C} 5^{-/-}\right)$and the corresponding B10.D2-Hc1 $\left(\mathrm{C}^{+/+}\right)$mice to intravenously inoculated S. aureus. a Survival of B10.D2-Hc0 and B10.D2-Hc1 after intravenous inoculation with $4 \times 10^{7} \mathrm{CFU}$ of $S$. aureus. b Bacterial loads in kidneys of those mice at $24 \mathrm{~h}$ after bacterial inoculation. Each bar represents the mean \pm SD of a minimum of 5 mice/group. ${ }^{* *} \mathrm{p}<0.01$.

trol animals at a small region of the genome containing a mutant allele at the $\mathrm{C} 5$ locus, to confirm the specific role of $\mathrm{C} 5$ in host response to $S$. aureus blood infection. Animals from both strains were intravenously inoculated with $4 \times 10^{7} \mathrm{CFU}$ of $S$. aureus and lethality was recorded for a period of 14 days. All B10.D2-Hc0 $\left(\mathrm{C}^{-/-}\right)$mice succumbed by the third day after challenge, compared to $30 \%$ of the B10.D2-Hc1 $\left(\mathrm{C} 5^{+/+}\right)$animals, of which $40 \%$ were still alive at day 14 (fig. 3a). In conjunction with these data, the B10.D2-Hc0 $\left(\mathrm{C}^{-/-}\right)$mice were less capable than B10.D2-Hc1 $\left(\mathrm{C}^{+/+}\right)$animals of controlling bacterial growth, as shown by the significantly higher amount of $S$. aureus in the kidneys at $24 \mathrm{~h}$ of infection (fig. $3 \mathrm{~b}$ ). These results confirm that $\mathrm{C} 5$ per se exerts a major impact in host defense in this experimental model of $S$. aureus bacteremia. However, the observation that B10.D2$\mathrm{Hcl}\left(\mathrm{C}^{+/+}\right)$mice are more susceptible to $S$. aureus than $\mathrm{C} 57 \mathrm{BL} / 6\left(\mathrm{C}^{+/+}\right)$animals also suggests the presence of additional genetic determinants in the B10.D2 background involved in its susceptibility to this pathogen.

\section{Conclusions}

Taken together, these data provide compelling evidence for a protective role of C5a during $S$. aureus bacteremia. C5 deficiency impairs host resistance to bloodborne $S$. aureus, resulting in uncontrolled bacterial growth in the kidneys, concomitant tissue damage and death. The pathological effects of C5 deficiency can be restored by adoptive transfer of $\mathrm{C} 5$-sufficient serum or by exogenous administration of $\mathrm{rC} 5 \mathrm{a}$. These findings may be of high relevance for the development of new therapeutic agents against staphylococcal bloodstream infections.

Interestingly, blockade of $\mathrm{C} 5 \mathrm{a}$ has been proposed as an attractive strategy for the treatment of sepsis in humans [13-15], when excessive production of C5a contributes to the immunopathogenesis (severity) of sepsis and septic shock by amplifying the inflammatory cascade, resulting in neutrophil dysfunction and vascular damage [16]. However, all these studies have been performed using experimental models of Gram-negative or polymicrobial sepsis (dominated by Gram-negative micro-organisms). Given that the frequency of Gram-positive bacterial infections such as $S$. aureus bloodstream infections as a cause of sepsis is increasing [17], it is evident that the riskbenefit relation of any new treatment strategy (e.g. blockade of C5a) should be carefully assessed for both Grampositive and Gram-negative septicemias.

\section{Acknowledgments}

The authors wish to thank Angelika Höhne and Claudia Höltje for excellent technical assistance, as well as Suzan Rooijakkers for critically reviewing the manuscript. This work was supported in part by BMBF-Suszeptibilität bei Infektionen: SkinStaph (FKZ: $01 \mathrm{kl07104}$ ) and in part by the Helmholtz Virtual Centre GeNeSys. 


\section{References}

$>1$ Lowy FD: Antimicrobial resistance: the example of Staphylococcus aureus. J Clin Invest 2003;111:1265-1273.

-2 Boucher HW, Corey GR: Epidemiology of methicillin-resistant Staphylococcus aureus. Clin Infect Dis 2008;46(suppl 5):S344-S349.

3 Frank MM, Fries LM: The role of complement in inflammation and phagocytosis. Immunol Today 1991;12:322-326.

-4 Guo RF, Ward PA: Role of C5a in inflammatory responses. Annu Rev Immunol 2005;23: 821-852.

5 Gasque P: Complement: a unique innate immune sensor for danger signals. Mol Immunol 2004;41:1089-1098.

6 Cerquetti MC, Sordelli DO, Ortegon RA, Bellanti JA: Impaired lung defenses against Staphylococcus aureus in mice with hereditary deficiency of the fifth component of complement. Infect Immun 1983;41:10711076.
7 Höpken UE, Lu B, Gerard NP, Gerard C: The C5a chemoattractant receptor mediates mucosal defence to infection. Nature 1996;383: 86-89.

$>8$ Naber CK: Future strategies for treating Staphylococcus aureus bloodstream infections. Clin Microbiol Infect 2008;14(suppl 2):26-34.

$\checkmark 9$ von Köckritz-Blickwede $M$, Rohde M, Oehmcke S, Miller LS, Cheung AL, Herwald $\mathrm{H}$, Foster S, Medina E: Immunological mechanisms underlying the genetic predisposition to severe Staphylococcus aureus infection in the mouse model. Am J Pathol 2008;173:1657-1668.

10 Nilsson UR, Müller-Eberhard HJ: Deficiency of the fifth component of complement in mice with an inherited complement defect. J Exp Med 1967;125:1-16.

11 Jacobs JC, Miller ME: Fatal familial Leiner's disease: a deficiency of the opsonic activity of serum complement. Pediatrics 1972;49: 225-232.

12 Delgado-Cerviño E, Fontán G, LópezTrascasa M: C5 complement deficiency in a Spanish family: molecular characterization of the double mutation responsible for the defect. Mol Immunol 2005;42:105-111.
13 Stevens JH, O’Hanley P, Shapiro JM, Mihm FG, Satoh PS, Collins JA, and Raffin TA: Effects of anti-C5a antibodies on the adult respiratory distress syndrome in septic primates. J Clin Invest 1986;77:1812-1816.

14 Czermak BJ, Sarma V, Pierson CL, Warner RL, Huber-Lang M, Bless NM, Schmal H, Friedl HP, Ward PA: Protective effects of C5a blockade in sepsis. Nat Med 1999;5:788792.

15 Laudes IJ, Chu JC, Sikranth S, Huber-Lang M, Guo RF, Riedemann N, Sarma JV, Schmaier AH, Ward PA: Anti-C5a ameliorates coagulation/fibrinolytic protein changes in a rat model of sepsis. Am J Pathol 2002; 160:1867-1875.

16 Ward PA: Role of the complement in experimental sepsis. J Leukoc Biol 2008;83:467470.

17 Martin GS, Mannino DM, Eaton S, Moss M: The epidemiology of sepsis in the United States from 1979 through 2000. N Engl J Med 2003;348:1546-1554. 